\title{
Iron(II) Complexes with Bio-Inspired N,N,O Ligands as Oxidation Catalysts: Olefin Epoxidation and cis-Dihydroxylation
}

\author{
Pieter C. A. Bruijnincx, ${ }^{[a]}$ Inge L. C. Buurmans, ${ }^{[a]}$ Silvia Gosiewska, ${ }^{[a]}$ \\ Marcel A. H. Moelands, ${ }^{[a]}$ Martin Lutz,${ }^{[b]}$ Anthony L. Spek, ${ }^{[b]}$ Gerard van Koten,,${ }^{[a]}$ and \\ Robertus J. M. Klein Gebbink*[a]
}

\begin{abstract}
The Rieske dioxygenases are a group of non-heme iron enzymes, which catalyze the stereospecific cis-dihydroxylation of its substrates. Herein, we report the iron(II) coordination chemistry of the ligands 3,3-bis(1methylimidazol-2-yl)propionate (L1) and its neutral propyl ester analogue propyl 3,3-bis(1-methylimidazol-2-yl)propionate (PrL1). The molecular structures of two iron(II) complexes with PrL1 were determined and two different coordination modes of the ligand were observed. In $\left[\mathrm{Fe}^{\mathrm{II}}(\mathbf{P r L 1})_{2}\right]-$ $\left(\mathrm{BPh}_{4}\right)_{2}(3)$ the ligand is facially coordi-
\end{abstract}

nated to the metal with an N,N,O donor set, whereas in $\left[\mathrm{Fe}^{\mathrm{II}}(\mathbf{P r L 1})_{2}\right.$ $\left.(\mathrm{MeOH})_{2}\right](\mathrm{OTf})_{2}$ (4) a bidentate $\mathrm{N}, \mathrm{N}$ binding mode is found. In $\mathbf{4}$, the solvent molecules are in a cis arrangement with respect to each other. Complex 4 is a close structural mimic of the crystallographically characterized nonheme iron(II) enzyme apocarotenoid15-15'-oxygenase (APO). The mechanistic features of APO are thought to

Keywords: hydrogen bonds • iron • $\mathrm{N}, \mathrm{N}, \mathrm{O}$ ligands $\cdot$ olefins $\cdot$ oxidation be similar to those of the Rieske oxygenases, the original inspiration for this work. The non-heme iron complexes $\left[\mathrm{Fe}^{\mathrm{II}}(\mathbf{P r L 1})_{2}\right](\mathrm{OTf})_{2} \quad$ (2) and $\left[\mathrm{Fe}^{\mathrm{II}}-\right.$ $\left.(\text { PrL1 })_{2}\right]\left(\mathrm{BPh}_{4}\right)_{2} \quad(3)$ were tested in olefin oxidation reactions with $\mathrm{H}_{2} \mathrm{O}_{2}$ as the terminal oxidant. Whereas 2 was an active catalyst and both epoxide and cis-dihydroxylation products were observed, 3 showed negligible activity under the same conditions, illustrating the importance of the anion in the reaction.

\section{Introduction}

The selective and catalytic oxidation of organic substrates is an important area of research in both academia and industry. ${ }^{[1]}$ Nature has developed several strategies for dioxygen activation and uses metalloenzymes to selectively oxidize and functionalize hydrocarbons. An important group of

[a] Dr. P. C. A. Bruijnincx, I. L. C. Buurmans, Dr. S. Gosiewska,

M. A. H. Moelands, Prof. Dr. G. v. Koten,

Prof. Dr. R. J. M. Klein Gebbink

Chemical Biology \& Organic Chemistry, Department of Chemistry

Faculty of Science, Utrecht University

Padualaan 8, $3584 \mathrm{CH}$ Utrecht (The Netherlands)

Fax:(+31)30-252-3615

E-mail: r.j.m.kleingebbink@uu.nl

[b] Dr. M. Lutz, Prof. Dr. A. L. Spek ${ }^{+}$

Bijvoet Center for Biomolecular Research, Crystal and Structural

Chemistry, Department of Chemistry,

Faculty of Science, Utrecht University

Padualaan 8, $3584 \mathrm{CH}$ Utrecht (The Netherlands)

E-mail: a.l.spek@uu.nl

$\left.{ }^{+}\right]$Correspondence pertaining to the crystallographic studies. these metalloenzymes are the non-heme iron oxygenases. ${ }^{[2,3]}$ A specific subset that utilizes a mononuclear, non-heme iron(II) center coordinated by the so-called 2-His-1-carboxylate facial triad has recently emerged as a common, versatile platform for these oxidative transformations. ${ }^{[4]}$ The Rieske dioxygenases belong to this class of enzymes and catalyze the stereospecific cis-dihydroxylation of arenes as the first step in the biodegradation of these compounds. Naphthalene 1,2-dioxygenase (NDO) was the first Rieske dioxygenase to be characterized crystallographically. ${ }^{[5]}$ The active site of NDO with bound substrate (Figure 1) features a mononuclear iron center coordinated by two histidines and a bidentate aspartate in a variation on the 2-His-1-carboxylate facial triad. ${ }^{[5]}$ This bidentate binding mode is found in some, but not all, crystallographically characterized Rieske dioxygenases. $^{[6]}$ Figure 1 also shows the cis-dihydroxylation reaction.

The unique reactivity of non-heme iron enzymes has inspired the development of synthetic non-heme iron complexes as potential oxidation catalysts. ${ }^{[1,2]}$ The family of tpaand bpmen-based catalysts (tpa: tris(2-pyridylmethyl)amine; bpmen: $N, N^{\prime}$-dimethyl- $N, N^{\prime}$-bis(2-pyridylmethyl)ethane-1,2- 


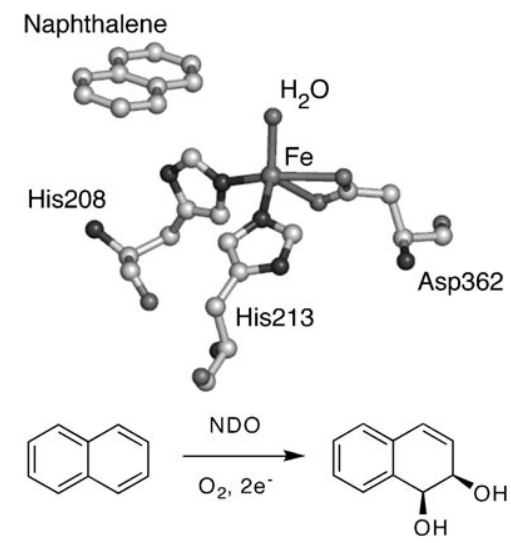

Figure 1. Active site of naphthalene 1,2-dioxygenase (NDO), a Rieske dioxygenase, with bound substrate (1O7G.pdb). The catalyzed cis-dihydroxylation reaction is also shown.

diamine) developed by Que et al., for instance, catalyze the epoxidation and/or cis-dihydroxylation of olefins with $\mathrm{H}_{2} \mathrm{O}_{2}$ as oxidant. ${ }^{[7-9]}$ These catalysts therefore serve as excellent functional models of the non-heme iron oxygenases. Other mononuclear iron systems capable of olefin epoxidation have also been reported. ${ }^{[10-14]}$ All ligands employed in these studies provide the metal center with an all-N donor set, which does not accurately reflect the $\mathrm{N}_{\mathrm{im}}, \mathrm{N}_{\mathrm{im}}, \mathrm{O}_{\text {carb }}$ ligand environment found at the active site of the enzymes. For this reason, attention has been devoted recently to the development of iron complexes with mixed donor ligands. ${ }^{[15-19]}$ Burzlaff et al., for example, have reported on the iron coordination chemistry of the bispyrazolylacetate $\mathrm{N}, \mathrm{N}, \mathrm{O}$ ligand system, ${ }^{[15,16]}$ and Que et al. recently communicated a very effective olefin cis-dihydroxylation catalyst based on the bis(2pyridyl)methylbenzamide ligand. ${ }^{[18]}$ A different approach to the isolation of mononuclear iron(II) complexes with a $\mathrm{N}, \mathrm{N}, \mathrm{O}_{\text {carboxylato }}$ donor set has also been reported recently; it involves the use of sterically hindered bidentate $\mathrm{N}$ and monodentate $\mathrm{O}$ donor ligands. ${ }^{[20]}$ Very recently, a mononuclear iron(II) complex has been reported with an N,N,O ligand, which accurately captures the bidentate coordination mode of the carboxylate, as found in some of the Rieske dioxygenases. This complex showed olefin cis-dihydroxylation, albeit with poor reactivity amounting to less than one turnover. ${ }^{[21]}$

As part of our efforts to build suitable models that mimic the active site of non-heme iron(II) enzymes, which exhibit the so-called 2-His-1-carboxylate facial triad, ${ }^{[2,4]}$ we have been studying the coordination chemistry of the substituted bis(1-alkylimidazol-2-yl)propionate ligand family ${ }^{[22,23]}$ and have synthesized mononuclear iron complexes that accurately mimic the coordination environment of the 2-His-1-carboxylate facial triad. ${ }^{[24]}$ Here, we describe the synthesis and structural characterization of bio-inspired iron(II) complexes with the ligand 3,3-bis(1-methylimidazol-2-yl)propionate (L1) and its neutral ester analogue propyl 3,3-bis(1methylimidazol-2-yl)propionate (PrL1). The latter com-

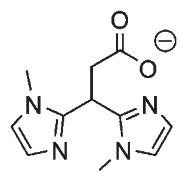

L1

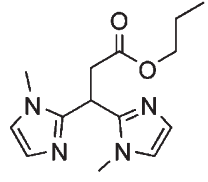

PrL1 plexes were found to be active catalysts in the epoxidation and cis-dihydroxylation of olefinic substrates.

\section{Results}

Synthesis and characterization of the iron(II) complexes 1-4: We have previously reported the synthesis and copper(II) coordination chemistry of the new bis(1-alkylimidazol-2-yl)propionate ligand family. ${ }^{[22,23]}$ In analogy to the $\left[\mathrm{CuL}_{2}\right]$ complexes, we synthesized the 2:1 iron(II) complex with ligand $\mathbf{L 1}$ (Figure 2). The addition of 0.5 equiv

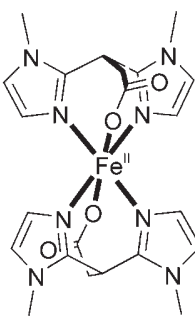

$\left[\mathrm{Fe}(\mathrm{L} 1)_{2}\right](1)$

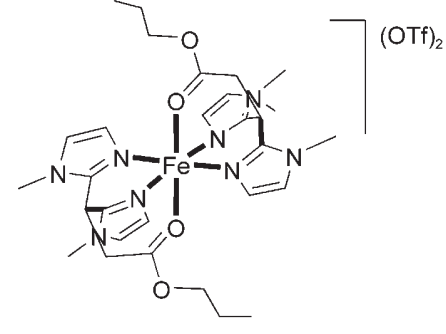

$\left[\mathrm{Fe}^{\mathrm{II}}(\mathrm{PrL} 1)_{2}\right](\mathrm{OTf})_{2}(2)$
Figure 2. Iron(II) complexes $\left[\mathrm{Fe}^{\mathrm{II}}(\mathbf{L 1})_{2}\right](\mathbf{1})$ and $\left[\mathrm{Fe}^{\mathrm{II}}(\mathbf{P r L 1})_{2}\right](\mathrm{OTf})_{2}(\mathbf{2})$

$\mathrm{Fe}^{\mathrm{II}}(\mathrm{OTf})_{2} \cdot 2 \mathrm{MeCN}$ to a solution containing the tetrabutylammonium salt of L1 (3,3-bis(1-methylimidazol-2-yl)propionate) in methanol resulted in the formation of neutral $\left[\mathrm{Fe}^{\mathrm{II}}(\mathbf{L 1})_{2}\right](\mathbf{1})$. The white product was analyzed by ESI-MS, IR spectroscopy, and elemental analysis. The ESI-MS and elemental analysis data point to the formation of a mononuclear, neutral species with a 2:1 ligand/metal ratio. The major peaks at $\mathrm{m} / z 523.00$ and 261.98 in the ESI-MS spectrum correspond to the $\left[\mathrm{Fe}(\mathbf{L 1})_{2}+\mathrm{H}\right]^{+}$and $\left[\mathrm{Fe}(\mathbf{L 1})_{2}+2 \mathrm{H}\right]^{2+}$ ions, respectively. The IR absorption spectrum obtained for the iron(II) complex is similar to that of the copper(II) complex ${ }^{[23]}$ and, most importantly, the asymmetric stretching vibration of the carboxylato group is found at the same frequency $\left(\tilde{v}_{\text {as }}=1580 \mathrm{~cm}^{-1}\right)$. This indicates that the carboxylato group is bound to the metal in the same fashion. The symmetric stretch of the carboxylato group is assigned to the absorption at $1392 \mathrm{~cm}^{-1}$, which results in a $\Delta\left(\tilde{v}_{\mathrm{as}}-\tilde{v}_{\mathrm{s}}\right)$ of $188 \mathrm{~cm}^{-1}$. It has been shown recently that this $\Delta$ value is determined by the coordination mode symmetry and thus provides a useful structural probe. ${ }^{[25]}$ The $\Delta\left(\tilde{v}_{\text {as }}-\tilde{v}_{\mathrm{s}}\right)$ value is identical to $\Delta\left(\tilde{v}_{\mathrm{as}}-\tilde{v}_{\mathrm{s}}\right)_{\text {ionic }}$ obtained for the corresponding free carboxylate $K[\mathbf{L 1}]^{[23]}$ and thus is indicative of a monodentate binding mode of the carboxylate. ${ }^{[25]}$ Based on these data, it 
is proposed that $\left[\mathrm{Fe}^{\mathrm{II}}(\mathbf{L 1})_{2}\right](\mathbf{1})$ is isostructural with the corresponding copper(II) complex $\left[\mathrm{Cu}^{\mathrm{II}}(\mathbf{L 1})_{2}\right]^{[23]}$ (Figure 2). Two L1 ligands facially cap the iron(II) metal center in $\mathbf{1}$ through both imidazole $\mathrm{N}$ and the carboxylato $\mathrm{O}$ donor atoms, very similarly to the coordination observed for the 2His-1-carboxylate facial triad. ${ }^{[2,4]}$ The solution magnetic moment of $\mathbf{1}$ in $\mathrm{D}_{2} \mathrm{O}$ as determined by Evans' NMR method $^{[26,27]}$ amounts to $5.2 \mu_{\mathrm{B}}$, which is consistent with a high-spin configuration $(S=2)$ at ambient temperature. Unfortunately, attempts at obtaining single crystals of complex $\mathbf{1}$ for X-ray analysis failed.

Preliminary catalytic results in alkane and alkene oxidations with $\mathrm{H}_{2} \mathrm{O}_{2}$ showed that $\mathbf{1}$ is not an active catalyst for these kinds of transformations (vide infra). Therefore, we also synthesized iron(II) complexes with the neutral ligand PrL1 (propyl 3,3-bis(1-methylimidazol-2-yl)propionate), the propyl ester precursor of L1. The mononuclear complex $\left[\mathrm{Fe}^{\mathrm{II}}(\mathbf{P r L 1})_{2}\right](\mathrm{OTf})_{2}(\mathbf{2})$ was synthesized by reaction of PrL1 ( 2 equiv) with $\mathrm{Fe}^{\mathrm{II}}(\mathrm{OTf})_{2} \cdot \mathrm{MeCN}$ in methanol, affording an off-white solid that could be recrystallized from acetonitrile/ diethyl ether. In the IR absorption spectrum of $\mathbf{2}$ the $\tilde{v}(\mathrm{C}=\mathrm{O})$ absorption frequency appears at $1689 \mathrm{~cm}^{-1}$, a shift of $35 \mathrm{~cm}^{-1}$ to lower wavenumbers compared to the free ligand $\left(\tilde{v}(\mathrm{C}=\mathrm{O}): 1724 \mathrm{~cm}^{-1}\right)$. A similar shift has been observed previously upon coordination of an ester carbonyl functionality to an iron(II) metal center ${ }^{[17]}$ Furthermore, the four sharp single vibrations at $1259\left(\tilde{v}_{\mathrm{as}} \mathrm{SO}_{3}\right), 1216\left(\tilde{v}_{\mathrm{s}} \mathrm{CF}_{3}\right)$, $1153\left(\tilde{v}_{\mathrm{as}} \mathrm{CF}_{3}\right)$, and $1030\left(\tilde{\nu}_{\mathrm{s}} \mathrm{SO}_{3}\right) \mathrm{cm}^{-1}$ are indicative of the presence of noncoordinated triflate anions. ${ }^{[17,28,29]}$ This implies that each PrL1 is coordinated as a tridentate N,N,O ligand (Figure 2). This notion is further corroborated by the $\mathrm{X}$-ray crystal structure determination of the complex $\left[\mathrm{Fe}^{\mathrm{II}}\right.$ $\left.(\text { PrL1 })_{2}\right]\left(\mathrm{BPh}_{4}\right)_{2}$ (3) (vide infra), which features two facially coordinated PrL1 ligands. The solution magnetic moment of $\left[\mathrm{Fe}^{\mathrm{II}}(\mathbf{P r L 1})_{2}\right](\mathrm{OTf})_{2} \quad(\mathbf{2})$ in $\left[\mathrm{D}_{6}\right]$ acetone was found to be $5.1 \mu_{\mathrm{B}}$, consistent with a high-spin iron(II) metal center.

To exclude any possible coordination of the anion to the metal in solution and/or participation of the anion in hydrogen bonding, such as that observed in $\mathbf{4}$ (vide infra), we exchanged the triflates in $\mathbf{2}$ for the noncoordinating tetraphenylborate anions. $\left[\mathrm{Fe}(\operatorname{PrL1})_{2}\right]$ $\left(\mathrm{BPh}_{4}\right)_{2}(3)$ was synthesized by addition of a methanolic solution of $\mathrm{NaBPh}_{4}$ to a solution of 2 in methanol followed by addition of water, which resulted in immediate precipitation of the crude product. The product was recrystallized from an acetonitrile/diethyl ether mixture and characterized by IR spectroscopy, ESI-MS, elemental analysis, and X-ray crystal structure determination. The sharp carbonyl stretch vibration observed at $1677 \mathrm{~cm}^{-1}$ (4) again reflects the coordination of the carbonyl group of the ester functionality to the iron(II) metal center. $\left[\mathrm{Fe}(\operatorname{PrL1})_{2}\right]-$ $\left(\mathrm{BPh}_{4}\right)_{2}(3)$ is a high-spin iron(II) complex $\left(\mu_{\mathrm{eff}}=5.0 \mu_{\mathrm{B}}\right)$. From the data given above it can be concluded that $\mathbf{2}$ and $\mathbf{3}$ have isostructural cations in the solid state.

Crystal structure of $\left[\mathrm{Fe}(\mathrm{PrL1})_{2}\right]\left(\mathrm{BPh}_{4}\right)_{2}(3)$ : Colorless crystals of $\mathbf{3}$ suitable for X-ray diffraction were obtained by slow evaporation of a dichloromethane solution of $\mathbf{3}$. The molecular structure of the cation of $\mathbf{3}$ is depicted in Figure 3; se-

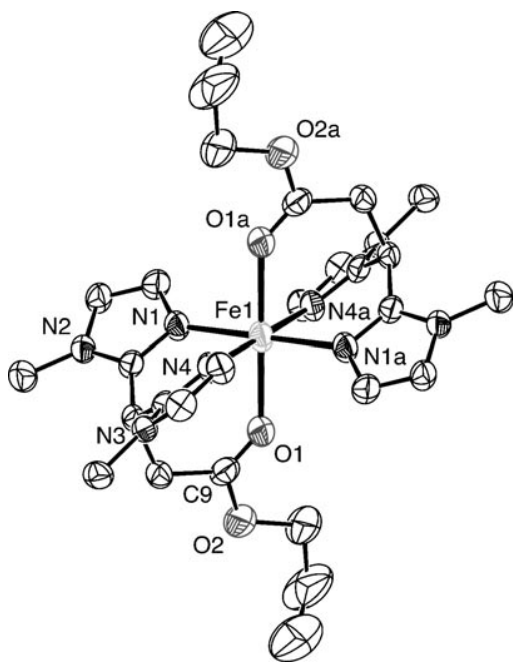

Figure 3. Molecular structure of the $\left[\mathrm{Fe}^{\mathrm{II}}(\mathbf{P r L 1})_{2}\right]^{2+}$ cation of $\mathbf{3}$ in the crystal. All hydrogen atoms, the tetraphenylborate anions, and disordered solvent molecules have been omitted for clarity. Displacement ellipsoids are drawn at the $50 \%$ probability level. Symmetry operation $a$ : $1-x$, $1-y, 1-z$.

lected bond lengths and angles of $\mathbf{3}$ are presented in Table 1.

The crystal structure of $\mathbf{3}$ consists of discrete mononuclear molecules. The iron(II) metal ion is situated on a crystallographic inversion center and two neutral PrL1 ligands are

Table 1. Selected bond lengths $[\AA]$ and angles $\left[^{\circ}\right]$ for $\left[\mathrm{Fe}(\mathbf{P r L 1})_{2}\right]\left(\mathrm{BPh}_{4}\right)_{2}(\mathbf{3})$ and $\left[\mathrm{Fe}(\mathbf{P r L 1})_{2}(\mathrm{MeOH})_{2}\right](\mathrm{OTf})_{2}$

\begin{tabular}{|c|c|c|c|c|c|}
\hline & Bond length & & Angle & & Angle \\
\hline \multicolumn{6}{|l|}{3} \\
\hline $\mathrm{Fe} 1-\mathrm{N} 1$ & $2.122(2)$ & N1-Fe1-N & $86.35(9)$ & N1-Fe1-N4a & $93.66(9)$ \\
\hline $\mathrm{Fe} 1-\mathrm{N} 4$ & $2.100(2)$ & N4-Fe1-O1 & $87.94(8)$ & N1-Fe1-O1a & $93.41(9)$ \\
\hline $\mathrm{Fe} 1-\mathrm{O} 1$ & $2.228(2)$ & N1-Fe1-O1 & $86.60(9)$ & N4-Fe1-O1a & $92.06(8)$ \\
\hline C9-O1 & $1.216(4)$ & & & & \\
\hline $\mathrm{C} 9-\mathrm{O} 2$ & $1.332(4)$ & & & & \\
\hline \multicolumn{6}{|l|}{4} \\
\hline Fe1-N11 & $2.161(2)$ & N32-Fe1-O2 & $171.23(8)$ & N31-Fe1-N32 & $101.75(8)$ \\
\hline $\mathrm{Fe} 1-\mathrm{N} 12$ & $2.154(2)$ & N11-Fe1-N12 & $175.78(8)$ & N32-Fe1-O1 & $84.80(8)$ \\
\hline Fe1-N31 & $2.135(2)$ & N31-Fe1-O1 & $171.65(8)$ & O1-Fe1-O2 & $86.62(8)$ \\
\hline $\mathrm{Fe} 1-\mathrm{N} 32$ & $2.170(2)$ & & & O2-Fe1-N31 & $86.96(8)$ \\
\hline Fe1-O1 & 2.1941(19) & N11-Fe1-N31 & $84.58(8)$ & N12-Fe1-N32 & $84.63(8)$ \\
\hline \multirow[t]{3}{*}{$\mathrm{Fe} 1-\mathrm{O} 2$} & $2.209(2)$ & N31-Fe1-N12 & $97.79(8)$ & N32-Fe1-N11 & $91.48(8)$ \\
\hline & & N12-Fe1-O1 & $87.89(8)$ & N11-Fe1-O2 & $90.33(8)$ \\
\hline & & O1-Fe1-N11 & $90.13(8)$ & O2-Fe1-N12 & $93.27(8)$ \\
\hline
\end{tabular}


arranged centrosymmetrically around the metal. The ligands cap the metal center facially through all three donor groups, that is, two 1-methylimidazole nitrogen atoms and the carbonyl oxygen of the ester functionality, resulting in a six-coordinate iron(II) metal center with an $\mathrm{N}_{4} \mathrm{O}_{2}$ donor set and nearly ideal octahedral geometry. The deviation from ideal octahedral geometry is reflected in the (diminished) angles, which are mainly dictated by the inherent geometrical restrictions imposed by the tripodal ligand. The $\mathrm{Fe}-\mathrm{N}$ distan-

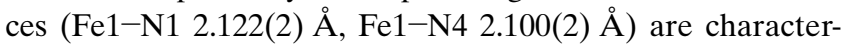
istic of a high-spin iron(II) metal center and are comparable to those found in high-spin iron(II) complexes with polyimidazole ligands. ${ }^{[30,31]}$ The structure is similar to the iron(II) complex $\left[\mathrm{Fe}^{\mathrm{II}}(\mathrm{Ph}-\mathrm{dpah})_{2}\right](\mathrm{OTf})_{2}$ (Ph-dpah: bis(2-pyridyl)methylbenzamide) reported recently by Que et al. ${ }^{[18]}$ featuring an $\mathrm{N}_{4} \mathrm{O}_{2}$ donor set of four pyridines and two amide carbonyl oxygens. Although the average $\mathrm{Fe}-\mathrm{N}$ bonds in $\mathbf{3}$ are shorter than those in $\left[\mathrm{Fe}^{\mathrm{II}}(\mathrm{Ph}-\mathrm{dpah})_{2}\right](\mathrm{OTf})_{2}(2.11 \AA$ versus $2.18 \AA)$, the Fe1-O1 bond (2.228(2) $\AA$ ) in $\mathbf{3}$ is considerably longer than the amide carbonyl oxygen to iron bond (2.043 $\AA$ ). This difference in the coordination strength of an amide carbonyl and an ester carbonyl to an iron(II) metal center has been observed before. ${ }^{[32]}$ The coordination of an ester group to an iron(II) metal center is quite rare and only a few structurally characterized examples have been reported. ${ }^{[17,32-34]}$

Crystal structure of $\left[\mathrm{Fe}(\operatorname{PrL1})_{2}(\mathrm{MeOH})_{2}\right]\left(\mathrm{OTf}_{2}\right.$ (4): Recrystallization of $\left[\mathrm{Fe}(\mathbf{P r L 1})_{2}\right](\mathrm{OTf})_{2}$ (2) from methanol and diethyl ether resulted in the formation of complex 4, whose structure was determined by X-ray diffraction. In [Fe$\left.(\text { PrL1 })_{2}(\mathrm{MeOH})_{2}\right](\mathrm{OTf})_{2}(4)$, the ester carbonyl functionalities of both ligands are not coordinated to the $\mathrm{Fe}^{\mathrm{II}}$ metal center. IR analysis of the crystals showed that the carbonyl stretch vibration $\tilde{v}(\mathrm{C}=\mathrm{O})$ is split into two signals at 1732 and $1724 \mathrm{~cm}^{-1}$ of almost equal intensity, close to the value of the free ligand. The two signals are probably the result of the slightly different orientations of the ligands around the metal ion, as seen in the crystal structure of 4 . The solution magnetic moment of $\left[\mathrm{Fe}(\mathbf{P r L 1})_{2}(\mathrm{MeOH})_{2}\right](\mathrm{OTf})_{2}$ (4) in $\left[\mathrm{D}_{6}\right.$ ]acetone is $5.2 \mu_{\mathrm{B}}$, consistent with a high-spin iron(II) complex. Colorless crystals of $\mathbf{4}$ suitable for X-ray diffraction were obtained by slow diffusion of diethyl ether into a solution of $\mathbf{2}$ in methanol. The molecular structure of $\mathbf{4}$ is given in Figure 4; selected bond lengths and angles are presented in Table 1.

The crystal structure of $\mathbf{4}$ consists of discrete mononuclear molecules. In the complex cation of $\mathbf{4}$, two ligands PrL1 bind to the metal center in an N,N bidentate fashion through the $\mathrm{N}$ donor atoms of the 1-methylimidazole groups. The propoxy group of one of the noncoordinated ester groups is disordered over two positions with occupancies of $62.1 \%$ and $37.9 \%$ for the major and minor component, respectively. The orientation of the ligands resembles that found in $\left[\mathrm{Fe}^{\mathrm{II}}(\mathrm{L})_{2}(\mathrm{OH})\right] \mathrm{BF}_{4}(\mathrm{~L}$ : bis(1-methylimidazol-2yl)-3-methylthiopropanol), in which the thioether tail is similarly pointing away from the metal center. ${ }^{[30]}$ The fifth and sixth coordination sites are occupied by two cis-positioned

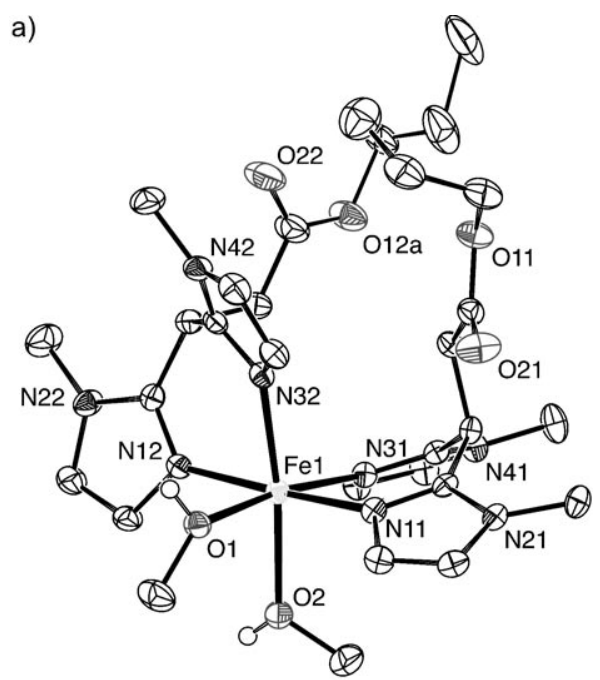

b)

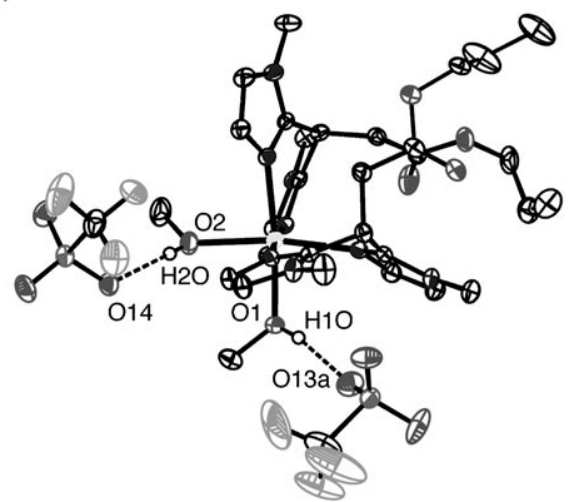

Figure 4. a) Molecular structure of the $\left[\mathrm{Fe}^{\mathrm{II}}(\mathbf{P r L 1})_{2}(\mathrm{MeOH})_{2}\right]^{2+}$ cation of 4 in the crystal. $\mathrm{C}-\mathrm{H}$ hydrogen atoms and triflate anions have been omitted for clarity. Only the major disorder component (62.1\% occupancy) of the disordered propoxy group is depicted. Displacement ellipsoids are drawn at the $50 \%$ probability level. b) The hydrogen bonding pattern in $\left[\mathrm{Fe}^{\mathrm{II}}(\mathbf{P r L 1})_{2}(\mathrm{MeOH})_{2}\right](\mathrm{OTf})_{2}(\mathbf{4})$. Symmetry operation $a: x-1, y, z$.

methanol molecules, completing the distorted octahedral $\mathrm{N}_{4} \mathrm{O}_{2}$ coordination sphere around the iron(II) ion. The $\mathrm{Fe}^{-}$ $\mathrm{N}$ bond lengths are rather different, ranging from 2.135(2) $\AA$ for $\mathrm{Fe} 1-\mathrm{N} 31$ to $2.170(2) \AA$ for Fe1-N32. The imidazole groups at the longest and shortest distance are both located trans to a methanol molecule. The average $\mathrm{Fe}-\mathrm{N}$ distance is $2.16 \AA$, characteristic of a high-spin iron(II) species. The $\mathrm{Fe}-\mathrm{N}$ distances are greater than those observed in $[\mathrm{Fe}-$ $\left.(\text { PrL1 })_{2}\right]\left(\mathrm{BPh}_{4}\right)_{2}(3)$. The $\mathrm{Fe}-\mathrm{O}$ bond lengths of both methanol molecules are similar and on average amount to $2.20 \AA$, a value that compares well to the $\mathrm{Fe}-\mathrm{O}$ distance found for the methanol molecule located trans to a pyridine donor group $(\mathrm{Fe}-\mathrm{O}=2.195 \AA) \quad$ in $\quad\left[\mathrm{Fe}^{\mathrm{II}}(\mathrm{tpa})(\mathrm{MeOH})_{2}\right]-$ $\left(\mathrm{BPh}_{4}\right)_{2} \cdot \mathrm{MeOH} \cdot{ }^{[35]}$ Each methanol ligand is involved in a hydrogen bond, acting as a hydrogen bond donor with a triflate oxygen as acceptor. The hydrogen bonding pattern is shown in the Figure 4 inset and relevant angles and distances are given in Table 2. 
Table 2. Selected hydrogen bond lengths $[\AA]$ and angles $\left[{ }^{\circ}\right]$ for $\left[\mathrm{Fe}^{\mathrm{II}}\right.$ $\left.(\text { PrL1 })_{2}(\mathrm{MeOH})_{2}\right](\mathrm{OTf})_{2}(4) .^{[\mathrm{a}]}$

\begin{tabular}{lllll}
\hline $\mathrm{D}-\mathrm{H} \cdots \mathrm{A}^{[\mathrm{b}]}$ & $\mathrm{D}-\mathrm{H}$ & $\mathrm{H} \cdots \mathrm{A}$ & $\mathrm{D} \cdots \mathrm{A}$ & $\mathrm{D}-\mathrm{H} \cdots \mathrm{A}$ \\
\hline $\mathrm{O} 1-\mathrm{H} 10 \cdots \mathrm{O} 13 \mathrm{a}$ & $0.79(3)$ & $1.93(3)$ & $2.705(3)$ & $166(3)$ \\
$\mathrm{O} 2-\mathrm{H} 20 \cdots \mathrm{O} 14$ & $0.75(3)$ & $2.07(3)$ & $2.812(3)$ & $172(3)$ \\
\hline
\end{tabular}

[a] Symmetry operation $a: x-1, y, z)$. [b] D: donor; A: acceptor.

Solution structures of 2-4 (ESI-MS, solution IR, and ${ }^{19}$ F NMR spectra): The crystal structures of $\mathbf{3}$ and $\mathbf{4}$ illustrate the possibility of different binding modes of the ligand PrL1 to an $\mathrm{Fe}^{\mathrm{II}}$ ion. To determine the structure of the complexes in solution, the ESI-MS, solution IR, and ${ }^{19} \mathrm{~F}$ NMR spectra of complexes 2-4 were recorded. The position of the carbonyl stretch vibration was found to be indicative of the coordination mode of the ligand. Vibrations at distinct wavenumbers were observed for the coordinated and noncoordinated ester carbonyl group vibrations in the solid state (Table 3). The energies of these vibrations corroborate the structural information provided by the crystal structures. The solution IR spectra were found to be highly solvent-dependent. Unfortunately, due to the limited solubility of $\left[\mathrm{Fe}(\operatorname{PrL1})_{2}\right]-$ $\left(\mathrm{BPh}_{4}\right)_{2}(3)$ in methanol and dichloromethane, data could be obtained only for an acetonitrile solution of this compound. Interestingly, the IR spectra of $\mathbf{2}$ and $\mathbf{3}$ in acetonitrile are identical in the carbonyl absorption region (Figure 5c). Two absorptions at 1737 and $1702 \mathrm{~cm}^{-1}$ were observed, corresponding to noncoordinated and coordinated ester carbonyl
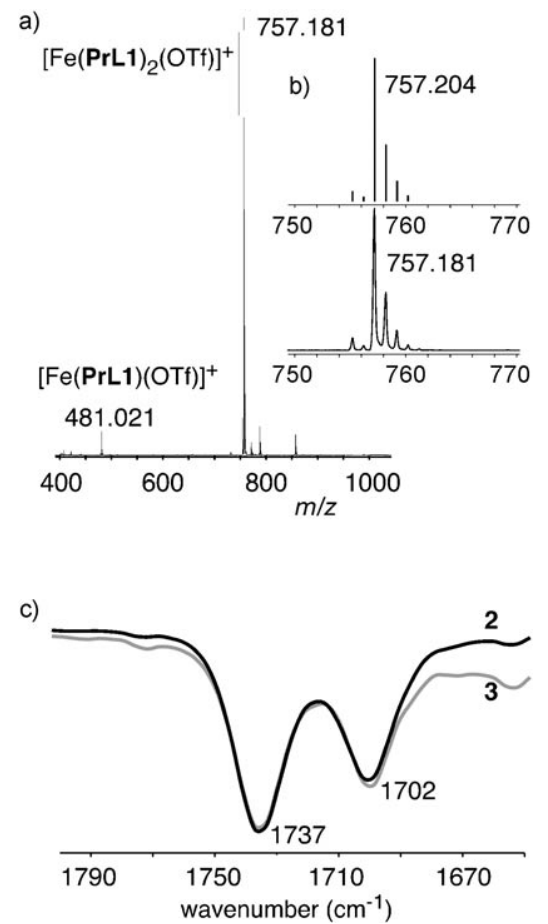

Figure 5. a) Electrospray ionization mass spectrum for $\mathbf{2}$ in methanol; b) measured and calculated isotope distribution patterns for the $\left\{\left[\mathrm{Fe}^{\mathrm{II}}-\right.\right.$ $\left.(\text { PrL1 })_{2}\right]($ OTf $\left.)\right\}^{+}$cation; c) solution IR spectra of $\mathbf{2}$ (black) and $\mathbf{3}$ (gray) in acetonitrile.
Table 3. Solid-state and solution IR vibrations of the carbonyl groups in complexes 2-4. ${ }^{[a]}$

\begin{tabular}{lccc}
\hline$v(\mathrm{C}=\mathrm{O})$ & $\mathbf{2}$ & $\mathbf{3}$ & $\mathbf{4}$ \\
{$\left[\mathrm{cm}^{-1}\right]^{\mathrm{b}]}$} & {$\left[\mathrm{Fe}(\mathbf{P r L 1})_{2}\right](\mathrm{OTf})_{2}$} & {$\left[\mathrm{Fe}(\mathbf{P r L 1})_{2}\right]\left(\mathrm{BPh}_{4}\right)_{2}$} & {$\left[\mathrm{Fe}(\mathbf{P r L 1})_{2}(\mathrm{MeOH})_{2}\right](\mathrm{OTf})_{2}$} \\
\hline solid & 1689 & 1677 & 1732,1724 \\
$\mathrm{MeCN}$ & $\mathbf{1 7 3 7}, 1702$ & $\mathbf{1 7 3 7}, 1702$ & n.d. $^{[\mathrm{d}]}$ \\
$\mathrm{MeOH}$ & $\mathbf{1 7 4 0}, 1704(\mathrm{sh})$ & i.s. ${ }^{[\mathrm{c}]}$ & $\mathbf{1 7 4 0}, 1707(\mathrm{sh})$ \\
$\mathrm{CH}_{2} \mathrm{Cl}_{2}$ & $1727(\mathrm{sh}), \mathbf{1 6 9 4}$ & i.s. & $1732, \mathbf{1 6 9 7}$
\end{tabular}

[a] The signal with the strongest absorption is reported in bold. [b] Free ligand PrL1: 1724 and $1735 \mathrm{~cm}^{-1}$ for solid-state and $\mathrm{MeCN}$ solution, resp. [c] i.s.: insufficiently soluble. [d] n.d.: not determined. broad and several shoulders were observed. This indicates that not all triflate anions are noncoordinated, but some of them are either directly bound to the metal center or involved in hydrogen bonds with coordinated solvent molecules. The ${ }^{19} \mathrm{~F} \mathrm{NMR}$ spectrum of $\mathbf{2}$ in methanol points to the latter option. Again one single, sharp

groups, respectively. Furthermore, four sharp vibrations at $1272,1227,1156$, and $1035 \mathrm{~cm}^{-1}$ were found for the triflate anions of $\mathbf{2}$. Indeed, the ${ }^{19} \mathrm{~F}$ NMR spectrum of $\mathbf{2}$ in acetonitrile shows one single, sharp signal at $\delta=-78.6$, corresponding to free triflate. ${ }^{[9]}$ The data suggest that dissociation of the ester groups and subsequent replacement with acetonitrile solvent molecules happens to the same extent for both 2 and 3. This is important, since vacant sites on the metal center are a necessary requirement for metal-based catalysis (vide infra). Identical spectra were also obtained for methanolic solutions of $\left[\mathrm{Fe}(\operatorname{PrL1})_{2}\right](\mathrm{OTf})_{2}$ (2) and $\left[\mathrm{Fe}(\operatorname{PrL1})_{2}\right.$ $\left.(\mathrm{MeOH})_{2}\right](\mathrm{OTf})_{2}(\mathbf{4})$, with the major carbonyl stretch at $1740 \mathrm{~cm}^{-1}$. This suggests that the ligand rearrangement process in methanol solution is quite facile and the structure of the cation of $\mathbf{2}$ and $\mathbf{4}$ in solution might resemble more the structure of the cation observed in the crystal structure of 4 . The vibrations associated with the triflate anions are rather signal at $\delta=-80.2$ is observed, which excludes direct binding to the metal since coordination to a paramagnetic center would cause a significant shift. Finally, spectra recorded in the noncoordinating solvent dichloromethane showed the carbonyl vibration around $1695 \mathrm{~cm}^{-1}$ for both 2 and $\mathbf{4}$, indicating coordination of the ester carbonyl functionalities. A small shoulder on this signal is observed at $1727 \mathrm{~cm}^{-1}$, indicating carbonyl group exchange to a small extent. This is corroborated by the ${ }^{19} \mathrm{~F}$ NMR spectrum of $\mathbf{2}$ in dichloromethane, which shows a single feature at $\delta=-65.7$. As the temperature is decreased the signal slightly broadens and gradually shifts to $\delta=-75.5$ upon cooling to $-80^{\circ} \mathrm{C}$. This points to a rapid equilibrium between coordinated and noncoordinated triflates, in which the latter predominate. When the temperature is decreased, the signal shifts to the value expected for free triflates and little or no fluxional exchange of the carbonyl group for triflate occurs. This coordinative 
saturation of $\mathbf{2}$ in dichloromethane causes the complex to be almost inactive in the oxidation reactions (vide infra).

ESI-MS measurements indicate the presence of mononuclear species in solution for all complexes (Figure 5a,b), with the $\left\{\left[\mathrm{Fe}(\mathbf{P r L 1})_{2}\right]\right\}^{2+}$ and $\left\{\left[\mathrm{Fe}(\mathbf{P r L 1})_{2}\right](\mathrm{X})\right\}^{+}\left(\mathrm{X}=\mathrm{OTf}, \mathrm{BPh}_{4}\right)$ ions as the major species. Interestingly, the 1:1 ligand/iron complex and free ligand are also observed in the ESI-MS spectrum $(\mathrm{m} / \mathrm{z}=481.021)$. This feature is not observed in dichloromethane solution (data not shown), which indicates that a ligand dissociation-association equilibrium exists only in coordinating solvents.

Oxidation catalysis: Complexes 1, 2, and $\mathbf{3}$ were tested in the oxidation of several different alkenes in acetonitrile solution with $\mathrm{H}_{2} \mathrm{O}_{2}$ as the oxidant. The catalytic reactions were performed at ambient conditions by slow, dropwise addition of 10 equiv $\mathrm{H}_{2} \mathrm{O}_{2}$ over $20 \mathrm{~min}$, in order to minimize peroxide disproportionation. The oxidations of styrene and cyclohexene were run under an $\mathrm{N}_{2}$ atmosphere to suppress autoxidation of the substrate. $\left[\mathrm{Fe}^{\mathrm{II}}(\mathbf{L 1})_{2}\right](\mathbf{1})$ was found to be incapable of catalyzing the oxidation of olefins with $\mathrm{H}_{2} \mathrm{O}_{2}$ as oxidant. The coordination of two monoanionic ligands in $\mathbf{1}$ probably results in relatively slow ligand exchange and hence coordinative saturation at the metal center. This in turn hampers the interaction of the metal with either peroxide or substrate and makes $\mathbf{1}$ ineffective in catalysis.

Table 4 summarizes the results obtained in the olefin oxidation experiments with 2 and 3. $\left[\mathrm{Fe}(\operatorname{PrL1})_{2}\right](\mathrm{OTf})_{2}$ (2) catalyzes the epoxidation and cis-1,2-dihydroxylation of various olefins with the conversion of $\mathrm{H}_{2} \mathrm{O}_{2}$ ranging from 39 to $51 \%$. The oxidation of cyclooctene with 10 equiv peroxide afforded a clean reaction with 1,2-epoxycyclooctane and cis1,2 -cyclooctanediol as the only products, with $39 \%$ efficiency and an epoxide/diol ratio of 2.5:1. A slight preference for epoxidation is also observed for the substrates styrene and cyclohexene. For 1-octene, the formation of the cis-diol product was favored over the epoxide by a factor of almost two. A small amount of benzaldehyde was found in the oxi- dation of styrene (TON 0.6 and 1.1 for $\mathbf{2}$ and $\mathbf{3}$, respectively) A considerable amount of the allylic oxidation product 2-cyclohexen-1-ol (7.9 turnovers), but no 2-cyclohexen-1-one, was observed with cyclohexene as a substrate. The addition of more equivalents of peroxide resulted in a gradual drop in efficiency of the catalytic conversion. Control experiments using the epoxides as potential substrates under standard reaction conditions did not result in cis-diol product formation, which showed that the diol product did not result from the epoxide under the experimental conditions. The stereoselectivity of the reactions was studied by the oxidation of the cis- and trans-2-heptene isomers. The epoxidation of cis-2-heptene and trans-2-heptene occurs with high stereoselectivity to the corresponding cis- and trans-epoxides, that is, with retention of configuration of $93 \%$ and $84 \%$, respectively. In addition, the cis-dihydroxylation of both substrates shows a high retention of configuration. The high stereoselectivity characterizes this oxidation as a true cis-dihydroxylation. We also tested $\mathbf{2}$ in the oxidation of 1-octene in dichloromethane. The use of this solvent rendered the complex almost completely inactive, with $\mathrm{TON}=0.1$ for epoxide and no cis-diol formation.

Interestingly, $\left[\mathrm{Fe}(\mathbf{P r L 1})_{2}\right]\left(\mathrm{BPh}_{4}\right)_{2}(3)$ is a rather poor catalyst under the reaction conditions tested. Low turnover numbers to epoxide are obtained in the oxidation of cyclooctene (0.8), styrene (1.2), 1-octene (0.2), and cyclohexene (0.6). No formation of diol is observed in these reactions. The difference in activity is remarkable, given the similar structure of the cations of $\mathbf{2}$ and $\mathbf{3}$ in solution (Figure 5). The influence of the anion on the accessible reaction pathways is therefore substantial and might be related to the possibility of hydrogen bonding interactions with the reactive iron-based oxidant and the chemical stability of the anion under the reaction conditions. Instead, significant amounts of biphenyl were observed in the GC traces of reaction mixtures with $\mathbf{3}$, pointing to the degradation of the $\mathrm{BPh}_{4}$ anion. To determine to what extent this observed difference in reactivity can be attributed to the reductive prop-

Table 4. Oxidation of alkenes catalyzed by $\left[\mathrm{Fe}(\mathbf{P r L 1})_{2}\right](\mathrm{OTf})_{2}(\mathbf{2})$ and $\left[\mathrm{Fe}(\mathbf{P r L 1})_{2}\right]\left(\mathrm{BPh}_{4}\right)_{2}(\mathbf{3})$ with $\mathrm{H}_{2} \mathrm{O}_{2}{ }^{[\mathrm{a}]}$

\begin{tabular}{|c|c|c|c|c|c|c|c|c|c|c|c|c|c|c|c|c|}
\hline \multirow[t]{2}{*}{ Substrate } & \multirow[t]{2}{*}{$\mathrm{H}_{2} \mathrm{O}_{2}$ [equiv] } & \multicolumn{4}{|c|}{ Epoxide $^{[\mathrm{b}]}$} & \multicolumn{4}{|c|}{ Diol $^{[b]}$} & \multicolumn{4}{|c|}{ Conversion $[\%]^{[\mathrm{c}]}$} & \multicolumn{3}{|c|}{ Epoxide/diol ratio } \\
\hline & & 2 & 3 & 5 & 6 & 2 & 3 & 5 & 6 & 2 & 3 & 5 & 6 & 2 & 5 & 6 \\
\hline \multirow[t]{2}{*}{ cyclooctene } & 10 & 2.8 & 0.8 & 0.5 & - & 1.1 & 0 & 7.0 & - & 39 & 8 & 75 & - & $2.5: 1$ & $1: 14$ & - \\
\hline & 20 & 3.8 & 1.5 & - & - & 1.5 & 0 & - & - & 27 & 8 & - & - & $2.5: 1$ & - & - \\
\hline \multirow[t]{2}{*}{ styrene $^{[\mathrm{d}, \mathrm{e}]}$} & 10 & 2.3 & 1.2 & 0.1 & - & 1.7 & 0 & 8.0 & - & 40 & 12 & 81 & - & $1.4: 1$ & $1: 80$ & - \\
\hline & 20 & 4.9 & 2.2 & - & - & 3.4 & 0 & - & - & 41 & 11 & - & - & $1.4: 1$ & - & - \\
\hline \multirow[t]{2}{*}{1 -octene $\mathrm{e}^{[\mathrm{f}]}$} & 10 & 1.6 & - & 0.1 & 0.1 & 2.7 & - & 7.6 & 0.7 & 43 & - & 77 & 8 & $1: 1.7$ & $1: 76$ & $1: 7$ \\
\hline & 20 & 2.4 & - & 0.2 & 0.1 & 4.5 & - & 10.3 & 0.6 & 35 & - & 53 & 4 & $1: 1.9$ & $1: 52$ & $1: 6$ \\
\hline \multirow[t]{2}{*}{ cyclohexene $\mathrm{e}^{[\mathrm{d}, \mathrm{g}]}$} & 10 & 3.0 & - & 0.7 & - & 2.1 & - & 6.2 & - & 51 & - & 69 & - & $1.4: 1$ & $1: 9$ & - \\
\hline & 20 & 5.0 & - & - & - & 3.9 & - & - & - & 45 & - & - & - & $1.3: 1$ & - & - \\
\hline trans-2-heptene & 20 & $3.2[93]^{[\mathrm{h}]}$ & - & - & - & $2.3[91]^{[\mathrm{h}]}$ & - & - & - & 28 & - & - & - & $1.4: 1$ & - & - \\
\hline cis-2-heptene & 20 & $6.2[84]^{[\mathrm{h}]}$ & - & - & - & $6.3[92]^{[\mathrm{h}]}$ & - & - & - & 63 & - & - & - & $1: 1$ & - & - \\
\hline
\end{tabular}

[a] Selected data from published alkene oxidation experiments on the other two reported iron complexes with a mixed $N, N, O$-donor set: that is, [Fe(Ph$\left.\mathrm{dpah})_{2}\right](\mathrm{OTf})_{2}(\mathbf{5})^{[18]}$ and $[\mathrm{Fe}(\mathrm{L})(\mathrm{OTf})](\mathbf{6})$ (ref. [21] have been included for comparison. [b] Yields expressed as turnover numbers $(\mathrm{TON}=\mathrm{mol}$ product/ mol catalyst). [c] Percentage conversion of $\mathrm{H}_{2} \mathrm{O}_{2}$ into epoxide and cis-diol. [d] Reaction performed under $\mathrm{N}_{2}$ atmosphere with deoxygenated solutions. [e] Some benzaldehyde formation was observed, with $\mathrm{TON}=0.6$ and 1.1 for $\mathbf{2}$ and $\mathbf{3}$, resp. [f] Oxidation of 1-octene catalyzed by $\mathbf{2}$ in dichloromethane (20 equiv $\mathrm{H}_{2} \mathrm{O}_{2}$ ) resulted in 0.1 equiv epoxide and no cis-diol product. [g] The allylic oxidation product 2-cyclohexen-1-ol was observed, with TON =7.9. $[\mathrm{h}]$ Retention of configuration (in brackets) $=100 \times(\mathrm{A}-\mathrm{B}) /(\mathrm{A}+\mathrm{B})$, where $\mathrm{A}$ is the cis-dihydroxylation product with retention and $\mathrm{B}$ is the epimer. 
erties of the tetraphenylborate anion, a blank experiment was done with sodium tetraphenylborate and hydrogen peroxide under the experimental conditions of the catalytic runs. Indeed, biphenyl formation was detected but significantly less $(\approx 25 \%)$ than observed in the catalytic runs with 3 present.

\section{Discussion}

The reaction of 2 equiv of ligand $\mathbf{L 1}$ or PrL1 with an $\mathrm{Fe}^{\mathrm{II}}$ metal source resulted in the formation of the 2:1 ligand/ metal complexes 1, 2, and 3. In $\left[\mathrm{Fe}^{\mathrm{II}}(\mathbf{L 1})_{2}\right](\mathbf{1})$, the ligand caps the metal center facially with an N,N,O donor set, similarly to the coordination observed at the active site of the mononuclear non-heme iron(II) enzymes featuring the 2His-1-carboxylate facial triad. ${ }^{[2,4]}$ In this respect, $\mathbf{1}$ is related to, yet distinct from the iron(II)-bispyrazolylacetate complexes developed by Burzlaff et al. ${ }^{[15,16]}$ Both ligand systems offer a monoanionic N,N,O donor set, but differ in the actual $\mathrm{N}$ donor groups. The X-ray crystal structure of $[\mathrm{Fe}-$ $\left.(\text { PrL1 })_{2}\right]\left(\mathrm{BPh}_{4}\right)_{2}(3)$ shows that PrL1 is also able to cap a metal center facially through all donor atoms. However, the structure of 4 illustrates that the tridentate, facial capping mode of PrL1 is not the only possible coordination mode of the ligand. In fact, solution IR measurements indicate the presence of both coordinated and noncoordinated carbonyl groups. It is interesting that the weakly bound carbonyl donor groups are located trans to each other in the solidstate structure of $\mathbf{3}$, whereas the two solvent molecules in $\mathbf{4}$ occupy cis positions relative to each other. This requires a rearrangement of the ligands with respect to each other. Dissolution of both $\mathbf{2}$ and $\mathbf{4}$ in either methanol or acetonitrile results in the formation of identical complexes in solution, according to solution IR and ESI-MS measurements; this indicates that such a rearrangement is quite facile under these conditions. The availability of two labile sites located cis to each other is important, since this is a necessary requirement for cis-dihydroxylation. ${ }^{[7,8]}$ The combination of (stepwise) ligand dissociation and/or rearrangement leads to many possible isomers in solution (Figure 6).

The combination of (solution) IR data and ESI-MS measurements suggests that all isomers are present in solution to a certain extent. The fact that $\mathbf{2}$ catalyzes the cis-dihydroxylation of alkenes implies that either species $\mathbf{G}$ or $\mathbf{F}$ contribute significantly to the catalytic reactions. The lack of catalytic activity in dichloromethane further emphasizes the necessity for complete or partial ligand dissociation.

Only a few mononuclear iron complexes capable of epoxidation and cis-dihydroxylation have been reported to date. ${ }^{[8,9,13,36]}$ The best-studied examples of catalysts that elicit this type of reactivity are the prototypical tpa- and bpmenbased catalysts, ${ }^{[7,8]}$ which both feature tetradentate N4 ligands. Related to these complexes are the N3py catalysts reported by Feringa et al. ${ }^{[13]}$ Only very recently the first examples of iron complexes with N,N,O ligands capable of olefin cis-dihydroxylation were reported. ${ }^{[18,21]}\left[\mathrm{Fe}(\operatorname{PrL1})_{2}\right](\mathrm{OTf})_{2}$ (2) adds a new example to this rather exclusive set of iron catalysts. Given the overall structural resemblance between $\left[\mathrm{Fe}(\mathrm{Ph}-\mathrm{dpah})_{2}\right](\mathrm{OTf})_{2}{ }^{[18]}$ and $\left[\mathrm{Fe}(\mathbf{P r L 1})_{2}\right](\mathrm{OTf})_{2}(\mathbf{2})$, the difference in selectivity for epoxide or cis-diol formation is remarkable. Whereas $\left[\mathrm{Fe}(\mathrm{Ph}-\mathrm{dpah})_{2}\right](\mathrm{OTf})_{2}$ yields a predominantly cis-diol product (it is the most efficient cis-dihydroxylation catalyst reported to date), $\mathbf{2}$ seems to favor epoxidation slightly.

The epoxide/diol product ratio has been correlated to the spin state of iron(III)-hydroperoxo intermediates, with highspin complexes leading to increased selectivity for the cisdiol product. ${ }^{[7]}$ Complex 2 features a high-spin metal center and is expected to yield a putative high-spin hydroperoxo intermediate upon reaction with $\mathrm{H}_{2} \mathrm{O}_{2}$, given the weak field exerted by the tridentate ligand. Yet $\mathbf{2}$ is more selective for

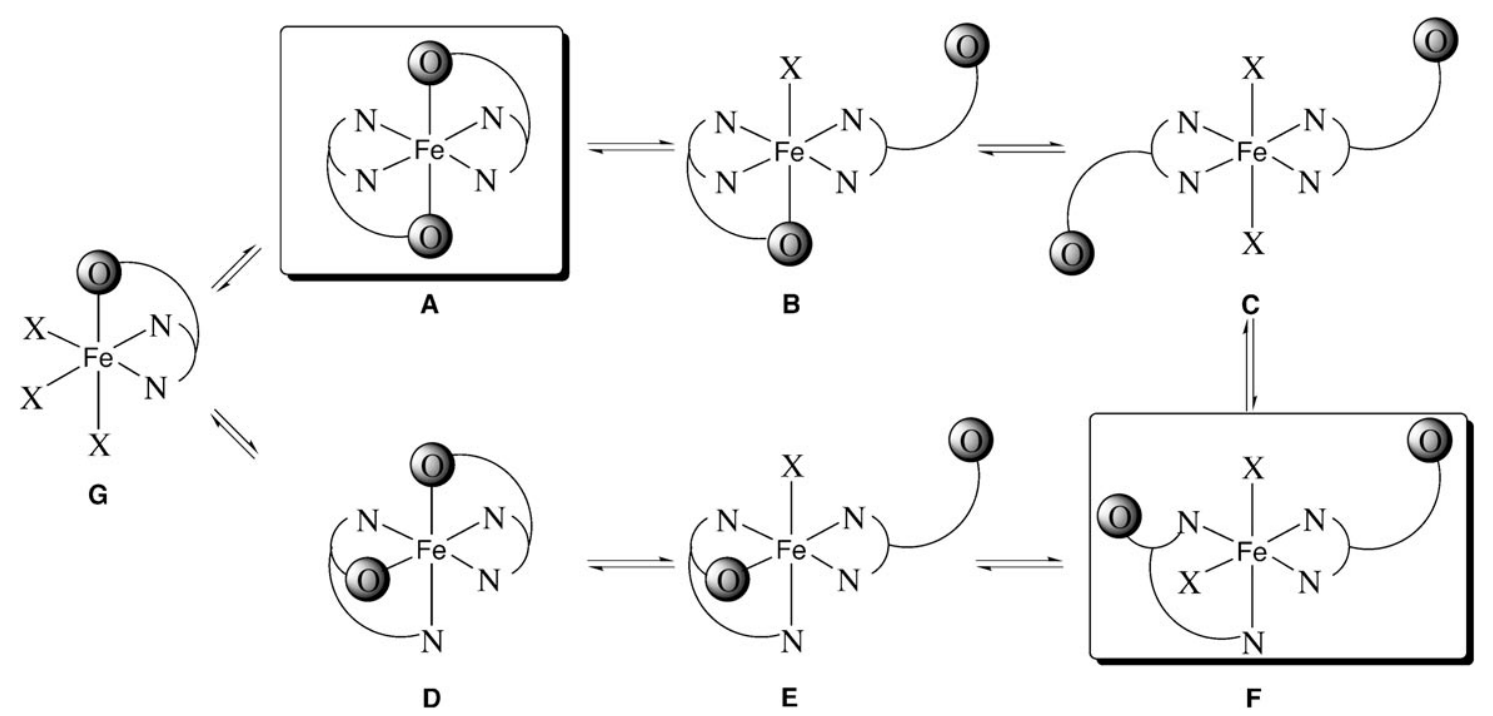

Figure 6. Possible solution structures of $\mathbf{2}$ and $\mathbf{3}$. X denotes solvent or OTf, depending on the compound and conditions. The boxed species correspond to the crystal structures of $\mathbf{3}$ and $\mathbf{4}$. 
epoxide formation. The formation of a purple species was observed in the reaction of both $\mathbf{2}$ and $\mathbf{3}$ with tert-butyl hydroperoxide at low temperature, which indicates the formation of a $\mathrm{Fe}^{\mathrm{III}}-\mathrm{OO} t \mathrm{Bu}$ species ${ }^{[37-39]}$ similar to the hydroperoxo intermediate invoked above. Interestingly, the purple species slowly converts into a second, green, intermediate. Further investigations of these intermediates and, for example, their spin states are currently under way.

The influence of the anion on the observed catalytic activity of $\mathbf{2}$ and $\mathbf{3}$ is remarkable. The exchange of triflate for tetraphenylborate anions results in a complete loss of cis-dihydroxylation activity and a greatly diminished epoxidation efficiency. Solution IR studies and ESI-MS measurements, however, suggest that the structures of the cations of $\mathbf{2}$ and $\mathbf{3}$ in acetonitrile are similar and the influence of the anions should therefore be attributed either to second-sphere interactions or to $\mathrm{BPh}_{4}$ anion degradation under the catalytic conditions (compare biphenyl formation). Precedents for the role of second-sphere noncovalent interactions, for example, hydrogen bonds, are found both in Nature and in biomimetic model systems. ${ }^{[40,41]}$ The interesting catalytic properties of $\mathbf{2}$ might therefore be correlated with the ability of triflate anions to accept hydrogen bonds and in this way stabilize reactive intermediates of the catalytic cycle.

Finally, the molecular structure of $\left[\mathrm{Fe}(\operatorname{PrL1})_{2}(\mathrm{MeOH})_{2}\right]-$ $(\mathrm{OTf})_{2}(4)$ is of interest because of its resemblance to the active site of apocarotenoid-15-15'-oxygenase (ACO), a retinal-forming carotenoid oxygenase. ${ }^{[42]}$ Carotenoids are precursors for retinal and its derivatives, which are crucial for vision and for the immune system. ${ }^{[43]}$ ACO catalyzes the oxidative cleavage of the $15-15^{\prime}$ double bond of its substrate. The crystal structure of the enzyme-substrate complex reveals a non-heme iron(II) active site, in which the metal center is coordinated by four histidine residues (Figure 7).$^{[42]}$
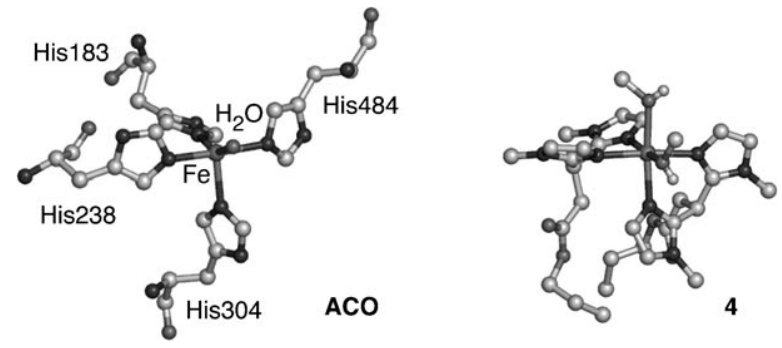

Figure 7. First coordination sphere of the mononuclear iron(II) enzyme apocarotenoid-15-15'-oxygenase (ACO, 2BIW.pdb) and that of complex $\left[\mathrm{Fe}(\mathbf{P r L 1})_{2}(\mathrm{MeOH})_{2}\right](\mathrm{OTf})_{2}(\mathbf{4})$.

This structural motif is relatively rare and has been reported in only four other enzymes. ${ }^{[44-47]}$ The coordination geometry around the iron in ACO is octahedral with an average $\mathrm{Fe}-\mathrm{N}_{\mathrm{im}}$ distance of $2.17 \AA$ and two cis-positioned coordination sites available for the binding of dioxygen. A water molecule occupies one of these sites, whereas the other is vacant in the reported crystal structure. $\left[\mathrm{Fe}^{\mathrm{II}}(\mathbf{P r L 1})_{2}\right.$ $\left.(\mathrm{MeOH})_{2}\right](\mathrm{OTf})_{2}$ (4) closely resembles the active site of apocarotenoid-15-15'-oxygenase (Figure 7). The biologically relevant 1-methylimidazole donor groups of PrL1 mimic the fourfold histidine coordination accurately. The average $\mathrm{Fe}-\mathrm{N}$ bond lengths $(2.16 \AA)$ agree well with the reported values. The second key structural feature is the availability of two cis-positioned vacant sites, which can be occupied by solvent molecules. The two coordinated methanol solvent molecules in 4 mimic this structural feature of the active site. The ester tails furthermore provide an entry into peptide chemistry to mimic the protein backbone and thus allow the inclusion of the second coordination sphere in modeling studies.

The oxidative cleavage of carotenoids was recently established as a dioxygenative process ${ }^{[48]}$ and a side-on binding of dioxygen to the metal center has been suggested. ${ }^{[42]}$ These mechanistic features are reminiscent of the Rieske dioxygenases,${ }^{[5]}$ which served as the inspiration for the biomimetic cis-dihydroxylation catalysts reported here. Further studies into the reactivity of the complexes presented here might shed light on possible mechanistic similarities between these two classes of non-heme iron enzymes.

\section{Conclusion}

As part of our recent efforts in the structural and functional modeling of non-heme iron enzymes featuring the 2-His-1carboxylate facial triad, we studied the iron(II) coordination chemistry of the potentially tridentate, tripodal N,N,O ligands $\mathbf{L 1}$ and PrL1. The molecular structures of 3 and 4 revealed two different binding modes of the new ligand PrL1, that is, tridentate N,N,O and bidentate N,N coordination, respectively. Solution studies, however, revealed the facile interconversion between the two different geometries. Complex $\left[\mathrm{Fe}^{\mathrm{II}}(\mathbf{P r L 1})_{2}\right](\mathrm{OTf})_{2}(\mathbf{2})$, but not complex $\left[\mathrm{Fe}^{\mathrm{II}}(\mathbf{P r L 1})_{2}\right]-$ $\left(\mathrm{BPh}_{4}\right)_{2}(\mathbf{3})$, was found to be an active catalyst in olefin oxidation reactions, which illustrates the importance of the anion. Complex 2 constitutes a new example of the rather exclusive class of non-heme iron catalysts, which are capable of catalyzing both the epoxidation and cis-dihydroxylation of substrates.

\section{Experimental Section}

Air-sensitive organic reactions were carried out under an atmosphere of dry, oxygen-free $\mathrm{N}_{2}$ using standard Schlenk techniques. THF and diethyl ether were dried over sodium benzophenone ketyl and distilled under $\mathrm{N}_{2}$ before use. Methanol was dried over magnesium methoxide and distilled under $\mathrm{N}_{2}$ before use. The air-sensitive iron complexes 1-4 were synthesized and handled under an $\mathrm{N}_{2}$ atmosphere using standard Schlenk techniques. Solvents were thoroughly deoxygenated with $\mathrm{N}_{2}$ before use. ${ }^{1} \mathrm{H}$ and ${ }^{13} \mathrm{C}\left\{{ }^{1} \mathrm{H}\right\}$ NMR spectra were recorded on a Varian AS400 or Varian Inova 300 spectrometer, operating at $25^{\circ} \mathrm{C}$. Infrared spectra were recorded with a Perkin-Elmer Spectrum One FT-IR instrument. Solution IR measurements were recorded with a Mettler Toledo ReactIR ${ }^{\circledR} 1000$ spectrometer with a SiComp ${ }^{\circledR}$ probe, which was fitted in a reaction vessel under an $\mathrm{N}_{2}$ atmosphere. GC analyses were performed on a PerkinElmer Autosystem XL GC (30 m, PE-17 capillary column) and a Perkin- 
Elmer Clarus 500 GC (30 m, Econo-Cap EC-5), both with FID detector. Elemental microanalyses were carried out by the Microanalytisches Laboratorium Dornis \& Kolbe, Mulheim a.d. Ruhr, Germany. ESI-MS spectra were recorded on a Micromass LC-TOF mass spectrometer at the Biomolecular Mass Spectrometry group, Utrecht University. UV/Vis spectra were recorded on a Varian Cary 50. Solution magnetic moments were determined by the Evans NMR method in $\mathrm{D}_{2} \mathrm{O} / 1$,4-dioxane $(95: 5 \mathrm{v} / \mathrm{v})(\mathbf{1})$ or $\left[\mathrm{D}_{6}\right]$ acetone/cyclohexane $(95: 5 \mathrm{v} / \mathrm{v})(\mathbf{2}-\mathbf{4})$ at $25^{\circ} \mathrm{C} .^{[26,27]}$ Tetrabutylammonium 3,3-bis(1-methylimidazol-2-yl)propionate $\left(\left[\mathrm{Bu}_{4} \mathrm{~N}\right]\right.$ $[\mathbf{L 1}]),{ }^{[23]}$ propyl 3,3-bis(1-methylimidazol-2-yl)propionate (PrL1), ${ }^{[23]}$ and $\mathrm{Fe}(\mathrm{OTf})_{2} \cdot 2 \mathrm{MeCN}^{[49]}$ were prepared according to published procedures. The epoxides of cis- and trans-2-heptenes were synthesized by stereoselective epoxidation of the olefins with $m$ CPBA. Hydrolysis of these epoxides by $\mathrm{HClO}_{4}$ in $\mathrm{H}_{2} \mathrm{O}$ /THF yielded the corresponding diols. All other chemicals were obtained commercially and used as received.

[Fe(L1) $)_{2}$ (1): A solution of $\mathrm{Fe}(\mathrm{OTf})_{2} \cdot 2 \mathrm{MeCN}(275 \mathrm{mg}, 0.31 \mathrm{mmol})$ in methanol $(10 \mathrm{~mL})$ was added to a solution of $\left[\mathrm{Bu}_{4} \mathrm{~N}\right][\mathbf{L 1}](300 \mathrm{mg}$, $0.63 \mathrm{mmol})$ in methanol $(20 \mathrm{~mL})$; a white precipitate formed gradually. The reaction mixture was stirred for $1 \mathrm{~h}$ at $50^{\circ} \mathrm{C}$, after which diethyl ether was added to precipitate the product. The crude product was separated by centrifugation and washed twice with diethyl ether $(2 \times 40 \mathrm{~mL})$. The product was obtained as a white powder $(161 \mathrm{mg}, 98 \%)$. IR (solid): $\tilde{v}=3120.2,2946.8,2906.3,2815.2,1580.2,1506.7,1426.0,1392.4,1310.1$, 1286.9, 1230.4, 1163.0, 1140.4, 1045.2, 953.3, 771.9, $753.3 \mathrm{~cm}^{-1}$; ESI-MS: $m / z=261.97\left\{[M+2 \mathrm{H}]^{2+}\right.$, calc. 262.08\}, $523.00\left\{[M+\mathrm{H}]^{+}\right.$, calc. 523.15\}; solution magnetic moment (Evans' method): $\mu_{\mathrm{eff}}=5.2 \mu_{\mathrm{B}}$; elemental analysis calcd (\%) for $\mathrm{C}_{22} \mathrm{H}_{26} \mathrm{FeN}_{8} \mathrm{O}_{4}$ (522.34): C 50.59, H 5.02, N 21.45; found C 50.28, H 4.92, N 21.30.

[Fe(PrL1) $\left.)_{2}\right](\text { OTf })_{2}$ (2): A solution of $\mathrm{Fe}(\mathrm{OTf})_{2} \cdot 2 \mathrm{MeCN} \quad(399 \mathrm{mg}$, $0.91 \mathrm{mmol})$ in methanol $(10 \mathrm{~mL})$ was added to a solution of PrL1 $(506 \mathrm{mg}, 1.83 \mathrm{mmol})$ in methanol $(15 \mathrm{~mL})$ and the reaction mixture was stirred for $30 \mathrm{~min}$. The solvent was evaporated in vacuo and the remaining off-white solid was recrystallized from an acetonitrile/diethyl ether mixture at $-30^{\circ} \mathrm{C}$ overnight. The product was obtained as a slightly greenish crystalline solid (430 mg, 52\%). IR (solid): $\tilde{v}=3126.5,2973.5$, 1689.1, 1506.7, 1404.4, 1258.9, 1215.6, 1152.4, 1029.9, 948.7, 782.1, $755.3 \mathrm{~cm}^{-1}$; ESI-MS: $m / z=277.12\left\{[\mathbf{P r L 1}+\mathrm{H}]^{+}\right.$, calc 277.17$\}, 304.00$ $\left\{[M-2 \mathrm{OTf}]^{2+}\right.$, calc. 304.13$\}, 481.02\left\{[\mathrm{M}-\text { PrL1-OTf }]^{+}\right.$, calc. 481.05$\}$, $757.20\left\{[M-\mathrm{OTf}]^{+}\right.$, calc. 757.18$\}$; solution magnetic moment (Evans' method): $\quad \mu_{\text {eff }}=5.1 \mu_{\mathrm{B}}$; elemental analysis calcd (\%) for $\mathrm{C}_{30} \mathrm{H}_{40} \mathrm{~F}_{6} \mathrm{FeN}_{8} \mathrm{O}_{10} \mathrm{~S}_{2}$ (906.65): C 39.34, H 4.45, N 12.36; found C 39.75, H 4.64, N 12.48 .

[Fe(PrL1) $\left.)_{2}\right]\left(\mathbf{B P h}_{4}\right)_{2}$ (3): A solution of $\mathrm{Fe}(\mathrm{OTf})_{2} \cdot 2 \mathrm{MeCN} \quad(246 \mathrm{mg}$, $0.56 \mathrm{mmol})$ in methanol $(10 \mathrm{~mL})$ was added to a solution of PrL1 $(312 \mathrm{mg}, 1.13 \mathrm{mmol})$ in methanol $(10 \mathrm{~mL})$ and the reaction mixture was stirred for $30 \mathrm{~min}$. Subsequently, a solution of $\mathrm{NaBPh}_{4}(1.1 \mathrm{~g}, 3.2 \mathrm{mmol})$ in methanol $(10 \mathrm{~mL})$ was added in a single portion to the reaction mixture and immediately a white precipitate formed. The addition of water $(50 \mathrm{~mL})$ to the suspension caused further precipitation of the product. The suspension was stirred for $20 \mathrm{~min}$, after which the solid was filtered off and washed three times with $\mathrm{H}_{2} \mathrm{O}(3 \times 20 \mathrm{~mL})$ to yield an off-white powder. The crude product was recrystallized from acetonitrile/diethyl ether at $-30^{\circ} \mathrm{C}$ to give the product as a slightly greenish crystalline solid (401 mg, 57\% yield). Single crystals of 3 suitable for X-ray diffraction were obtained by slow evaporation of a dichloromethane solution. IR (solid): $\tilde{v}=3139.2,3122.5,3052.5,2972.1,2860.8,1677.3,1579.5,1507.7$, $1479.4,1426.5,1388.2,1287.1,1268.0,1214.6,1178.4,1118.6,1064.6$, $1029.2,946.3,850.0,732.7,704.0 \mathrm{~cm}^{-1}$; ESI-MS: $m / z=303.99\{[M-2-$ $\left.\left(\mathrm{BPh}_{4}\right)\right]^{2+}$, calc. 304.13$\}, 927.33\left\{\left[M-\mathrm{BPh}_{4}\right]^{+}\right.$, calc. 927.42\}; solution magnetic moment (Evans' method): $\mu_{\text {eff }}=5.0 \mu_{\mathrm{B}}$; elemental analysis calcd (\%) for $\mathrm{C}_{76} \mathrm{H}_{80} \mathrm{~B}_{2} \mathrm{FeN}_{8} \mathrm{O}_{4}$ (1246.97): C 73.20, $\mathrm{H}$ 6.47, N 8.99; found $\mathrm{C} 73.28, \mathrm{H}$ $6.40, \mathrm{~N} 8.86$.

$\left[\mathrm{Fe}(\mathrm{PrL1})_{2}(\mathrm{MeOH})_{2}\right](\mathbf{O T f})_{2} \quad$ (4): Recrystallization of $\mathbf{2}$ (100 mg, $0.11 \mathrm{mmol}$ ) from a methanol/diethyl ether mixture at $-30{ }^{\circ} \mathrm{C}$ resulted in the formation of $\left[\mathbf{F e}(\operatorname{PrL1})_{2}(\mathbf{M e O H})_{2}\right](\mathbf{O T f})_{2}(4)$ as a white, microcrystalline solid after several days $(54 \mathrm{mg}, 50 \%)$. Slow vapor diffusion of diethyl ether into a solution of $\left[\mathbf{F e}(\operatorname{PrL1})_{2}\right](\mathbf{O T f})_{2}$ (2) in methanol at room temperature yielded colorless crystals suitable for X-ray diffraction. IR (solid): $\tilde{v}=3371.8,2969.5,1732.0,1723.7,1503.6,1421.6,1360.4,1281.1$, 1247.0, 1222.7, 1194.7, 1150.8, 1031.6, 1011.84, 977.3, 731.6 cm ${ }^{-1}$; ESI-MS : $m / z=303.96\left\{[M-2 \mathrm{OTf}]^{2+}\right.$, calc. 304.13$\}, 757.05\left\{[M-\mathrm{OTf}]^{+}\right.$, calc. 757.18\}; solution magnetic moment (Evans' method): $\mu_{\mathrm{eff}}=5.2 \mu_{\mathrm{B}}$; elemental analysis calcd (\%) for $\mathrm{C}_{32} \mathrm{H}_{48} \mathrm{~F}_{6} \mathrm{FeN}_{8} \mathrm{O}_{12} \mathrm{~S}_{2}$ (970.74): C 39.59, H 4.98, N 11.54; found C 39.40, H 5.02, N 11.59.

Catalysis protocol: Substrate (1000 equiv, $3 \mathrm{mmol}$ ) and acetonitrile (to bring the total volume to $2.5 \mathrm{~mL}$ ) were added to a solution of catalyst $(3 \mu \mathrm{mol})$ in acetonitrile $(2 \mathrm{~mL})$. Subsequently, $0.5 \mathrm{~mL}$ of oxidant solution (10 equiv, $60 \mathrm{~mm}$ solution in acetonitrile diluted from $35 \%$ aqueous $\mathrm{H}_{2} \mathrm{O}_{2}$ ) was added dropwise in $20 \mathrm{~min}$. The reaction mixture was stirred at room temperature and after $1 \mathrm{~h}$ (from the start of oxidant addition) internal standard (10 $\mu \mathrm{L}$ : cyclooctene/1,2-dibromobenzene; all other substrates: bromobenzene) was added and the first sample was taken. An aliquot of the reaction mixture was filtered over a short silica plug, after which the short column was flushed twice with diethyl ether. The sample was concentrated in a stream of $\mathrm{N}_{2}$ and analyzed by GC. The products were identified and quantified by comparison with authentic compounds.

X-ray crystal structure determinations: $X$-ray intensities were measured on a Nonius Kappa CCD diffractometer with rotating anode (graphite monochromator, $\lambda=0.71073 \AA$ ) at $150 \mathrm{~K}$. The structures were solved by automated Patterson methods ${ }^{[50]}(3)$ or direct methods ${ }^{[51]}(4)$ and refined with SHELXL-97 ${ }^{[52]}$ against $F^{2}$ of all reflections. Geometry calculations and checks for higher symmetry were performed with the PLATON program. ${ }^{[53]}$

X-ray crystal structure determination of 3: $\left[\mathrm{C}_{28} \mathrm{H}_{40} \mathrm{FeN}_{8} \mathrm{O}_{4}\right]\left(\mathrm{C}_{24} \mathrm{H}_{20} \mathrm{~B}\right)_{2}$, formula weight $=1246.95$, colorless block, $0.15 \times 0.15 \times 0.10 \mathrm{~mm}^{3}$, monoclinic, $P 2_{1} / c$ (no. 14), $a=14.9857(2), b=11.0234(2), c=24.7254(4) \AA, \beta=$ 119.7779(5) $)^{\circ}, \quad V=3545.14(10) \AA^{3}, \quad Z=2, \quad D_{x}=1.168 \mathrm{~g} \mathrm{~cm}^{-3}, * \quad \mu=$ $0.27 \mathrm{~mm}^{-1}$. 40742 Reflections were measured up to a resolution of $(\sin \theta /$ $\lambda)_{\max }=0.52 \AA^{-1}$. The reflections were corrected for absorption on the basis of multiple measured reflections (0.86-0.97 correction range). 4189 reflections were unique $\left(R_{\text {int }}=0.0845\right)$. Non-hydrogen atoms were refined with anisotropic displacement parameters. All hydrogen atoms were introduced in calculated positions and refined with a riding model. The crystal structure contains large voids, filled with disordered solvent molecules $\left(300.1 \AA^{3} /\right.$ unit cell). Their contribution to the structure factors was secured by back Fourier transformation with the SQUEEZE routine of the PLATON package ${ }^{[53]}$ (56 electrons/unit cell). 415 parameters were refined with no restraints. $R 1 / w R 2[I>2 \sigma(\mathrm{I})]: 0.0441 / 0.1095, R 1 / w R 2$ [all refl.]: $0.0652 / 0.1197$. $S=1.047$. Residual electron density between -0.27 and $0.49 \mathrm{e}^{-3}$.

$X$-ray crystal structure determination of $4:\left[\mathrm{C}_{30} \mathrm{H}_{48} \mathrm{FeN}_{8} \mathrm{O}_{6}\right]\left(\mathrm{CF}_{3} \mathrm{SO}_{3}\right)_{2}$, formula weight $=970.75$, yellow needles, $0.85 \times 0.09 \times 0.06 \mathrm{~mm}^{3}$, triclinic, $P \overline{1}$ (no. 2), $a=8.9674(8), b=12.7224(16), c=19.9574(16) \AA, \alpha=106.688(3)$, $\beta=101.274(5), \gamma=91.638(4)^{\circ}, V=2130.2(4) \AA^{3}, Z=2, D_{x}=1.513 \mathrm{~g} \mathrm{~cm}^{-3}$, $\mu=0.55 \mathrm{~mm}^{-1} .37349$ reflections were measured up to a resolution of $(\sin \theta / \lambda)_{\max }=0.61 \AA^{-1}$, and corrected for absorption on the basis of multiple measured reflections (correction range 0.80-0.97); 7945 reflections were unique $\left(R_{\text {int }}=0.0436\right)$. Non-hydrogen atoms were refined with anisotropic displacement parameters. All hydrogen atoms were located in the difference Fourier map. The $\mathrm{O}-\mathrm{H}$ hydrogen atom was refined freely with isotropic displacement parameters; all other hydrogen atoms were refined with a riding model. The propoxy group was refined with a disorder model. 604 parameters were refined with 55 restraints. $R 1 / w R 2$ [I>2 $\sigma(I)$ ]: $0.0416 / 0.0844$. $R 1 / w R 2$ [all refl.]: $0.0691 / 0.0945 . S=1.050$. Residual electron density between -0.39 and 0.31 e $\AA^{-3}$.

CCDC 622570 (3) and 622571 (4) contain the supplementary crystallographic data for this paper. These data can be obtained free of charge from The Cambridge Crystallographic Data Centre via www.ccdc.cam. ac.uk/data_request/cif.

[*] Derived parameters do not contain the contribution of the disordered solvent. 


\section{Acknowledgements}

The work described here was supported financially by the National Research School Combination-Catalysis (P.C.A.B.) and the Council for Chemical Sciences of the Netherlands Organization for Scientific Research (CW-NWO) (M.L., A.L.S.).

[1] S. Tanase, E. Bouwman, Adv. Inorg. Chem. 2006, 58, 29.

[2] M. Costas, M. P. Mehn, M. P. Jensen, L. Que, Jr., Chem. Rev. 2004, $104,939$.

[3] E. I. Solomon, T. C. Brunold, M. I. Davis, J. N. Kernsley, S.-K. Lee, N. Lehnert, F. Neese, A. J. Skulan, Y.-S. Yang, J. Zhou, Chem. Rev. 2000, 100, 235.

[4] K. D. Koehntop, J. P. Emerson, L. Que, Jr., J. Biol. Inorg. Chem. 2005, 10, 87.

[5] A. Karlsson, J. V. Parales, R. E. Parales, D. T. Gibson, H. Eklund, S. Ramaswamy, Science 2003, 299, 1039.

[6] D. J. Ferraro, L. Gakhar, S. Ramaswamy, Biochem. Biophys. Res. Commun. 2005, 338, 175

[7] K. Chen, M. Costas, J. Kim, A. K. Tipton, L. Que, Jr., J. Am. Chem. Soc. 2002, 124, 3026.

[8] K. Chen, M. Costas, L. Que, Jr., J. Chem. Soc. Dalton Trans. 2002, 672.

[9] R. Mas-Ballesté, M. Costas, T. van den Berg, L. Que, Jr., Chem. Eur. J. 2006, 12, 7489.

[10] R. J. Guajardo, S. E. Hudson, S. J. Brown, P. K. Mascharak, J. Am. Chem. Soc. 1993, 115, 7971.

[11] W. Nam, R. Ho, J. S. Valentine, J. Am. Chem. Soc. 1991, 113, 7052.

[12] M. C. White, A. G. Doyle, E. N. Jacobsen, J. Am. Chem. Soc. 2001, 123,7194

[13] M. Klopstra, G. Roelfes, R. Hage, R. M. Kellogg, B. L. Feringa, Eur. J. Inorg. Chem. 2004, 846 .

[14] O. Rotthaus, S. Le Roy, A. Tomas, K. M. Barkigia, I. Artaud, Inorg. Chim. Acta 2004, 357, 2211.

[15] A. Beck, A. Barth, E. Hubner, N. Burzlaff, Inorg. Chem. 2003, 42, 7182

[16] A. Beck, B. Weibert, N. Burzlaff, Eur. J. Inorg. Chem. 2001, 521.

[17] S. Gosiewska, J. L. M. Cornelissen, M. Lutz, A. L. Spek, G. van Koten, R. J. M. Klein Gebbink, Inorg. Chem. 2006, 45, 4214

[18] P. D. Oldenburg, A. A. Shteinman, L. Que, Jr., J. Am. Chem. Soc. 2005, 127, 15673.

[19] A. Otero, J. Fernández-Baeza, A. Antiñolo, J. Tejeda, A. LaraSánchez, Dalton Trans. 2004, 1499.

[20] S. J. Friese, B. E. Kucera, L. Que, Jr., W. B. Tolman, Inorg. Chem. 2006, 45, 8003.

[21] P. D. Oldenburg, C.-Y. Ke, A. A. Tipton, A. A. Shteinman, L. Que, Jr., Angew. Chem. Int. Ed. 2006, 45, 7975.

[22] K. Kervinen, P. C. A. Bruijnincx, A. M. Beale, J. G. Mesu, G. van Koten, R. J. M. Klein Gebbink, B. M. Weckhuysen, J. Am. Chem. Soc. 2006, 128, 3208.

[23] P. C. A. Bruijnincx, M. Lutz, A. L. Spek, E. L. van Faassen, B. M. Weckhuysen, G. van Koten, R. J. M. Klein Gebbink, Eur. J. Inorg. Chem. 2005, 779 .

[24] P. C. A. Bruijnincx, M. Lutz, A. L. Spek, W. R. Hagen, B. M. Weckhuysen, G. van Koten, R. J. M. Klein Gebbink, J. Am. Chem. Soc., 2007, 129, 2275 .
[25] V. Robert, G. Lemercier, J. Am. Chem. Soc. 2006, 128, 1183.

[26] G. J. P. Britovsek, V. C. Gibson, S. K. Spitzmesser, K. P. Tellmann, A. J. P. White, D. J. Williams, J. Chem. Soc., Dalton Trans. 2002, 1159.

[27] D. F. J. Evans, J. Chem. Soc. 1959, 2003.

[28] S. P. Gejji, K. Hermansson, J. Lindgren, J. Phys. Chem. 1993, 97, 3712 .

[29] D. H. Johnston, D. F. Shriver, Inorg. Chem. 1993, 32, 1045.

[30] L. Bénisvy, S. Halut, B. Donnadieu, J.-P. Tuchagues, J.-C. Chottard, Y. Li, Inorg. Chem. 2006, 45, 2403.

[31] G. Lemercier, E. Mulliez, C. Brouca-Cabarrecq, F. Dahan, J.-P. Tuchagues, Inorg. Chem. 2004, 43, 2105.

[32] A. Ion, J.-C. Moutet, E. Saint-Aman, G. Royal, S. Tingry, J. Pecaut, S. Ménage, R. Ziessel, Inorg. Chem. 2001, 40, 3632.

[33] S. Szafert, T. Lis, K. Drabent, P. Sobota, J. Chem. Crystallogr. 1994, 24, 197.

[34] B. Weber, H. Görls, M. Rudolph, E.-G. Jäger, Inorg. Chim. Acta 2002, 337, 247.

[35] A. Diebold, K. S. Hagen, Inorg. Chem. 1998, 37, 215.

[36] P. D. Oldenburg, L. Que, Jr., J. Mol. Cat. A. 2006, 117, 15.

[37] S. Gosiewska, H. P. Permentier, A. P. Bruins, G. van Koten, R. J. M. Klein Gebbink, Dalton Trans. 2007, 3365.

[38] M. P. Jensen, M. Costas, R. Y. N. Ho, J. Kaizer, A. Mairata i Payeras, E. Münck, L. Que, Jr., J.-U. Rohde, A. Stubna, J. Am. Chem. Soc. 2005, 127, 9117.

[39] M. R. Bukowski, H. L. Halfen, T. van den Berg, J. A. Halfen, L. Que, Jr., Angew. Chem. Int. Ed. 2005, 44, 584.

[40] A. S. Borovik, Acc. Chem. Res. 2005, 38, 54.

[41] Y. Lu, J. S. Valentine, Curr. Opin. Struct. Biol. 1997, 7, 495.

[42] D. P. Kloer, S. Ruch, S. Al-Babili, P. Beyer, G. E. Schultz, Science 2005, 308, 267.

[43] G. Giuliano, S. Al-Babili, J. von Lintig, Trends Plant Sci. 2003, 8, 145

[44] K. N. Ferreira, T. M. Iverson, K. Maghlaoui, J. Barber, S. Iwata, Science 2004, 303, 1831.

[45] G. Katona, U. Andréasson, E. M. Landau, L.-E. Andréasson, R. Neutze, J. Mol. Biol. 2003, 331, 681.

[46] C. R. D. Lancaster, H. Michel, J. Mol. Biol. 1999, 286, 883.

[47] S. A. Gillmor, A. Villasenor, R. Fletterick, E. Sigal, M. F. Browner, Nat. Struct. Biol. 1997, 4, 1003.

[48] H. Schmidt, R. Kurtzer, W. Eisenreich, W. Schwab, J. Biol. Chem. 2006, 281, 9845 .

[49] K. S. Hagen, Inorg. Chem. 2000, 39, 5867.

[50] P. T. Beurskens, G. Admiraal, G. Beurskens, W. P. Bosman, S. Garcia-Granda, R. O. Gould, J. M. M. Smits, C. Smykalla, Technical Report of the Crystallography Laboratory, University of Nijmegen, The Netherlands, 1999.

[51] A. Altomare, M. C. Burla, M. Camalli, G. L. Cascarano, C. Giacovazzo, A. Guagliardi, A. G. G. Moliterni, G. Polidori, R. Spagna, J. Appl. Crystallogr. 1999, 32, 115 .

[52] G. M. Sheldrick, University of Göttingen, Germany, 1997.

[53] A. L. Spek, J. Appl. Crystallogr. 2003, 36, 7.

Received: April 13, 2007

Revised: September 18, 2007

Published online: November 19, 2007 